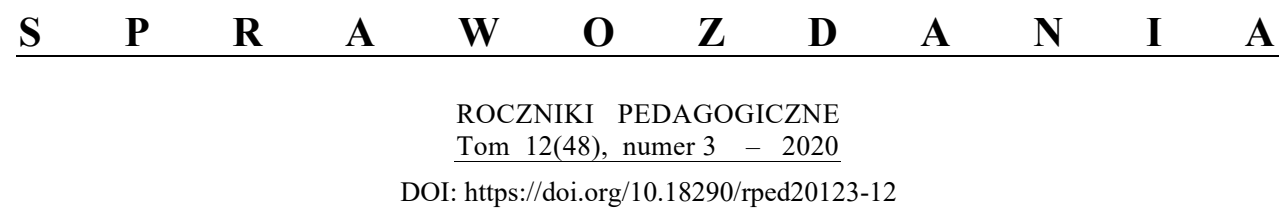

DR ANNA SZUDRA-BARSZCZ

Katedra Pedagogiki Ogólnej

Instytut Pedagogiki KUL

e-mail:szudra@kul.pl

ORCID: https://orcid.org/0000-0002-0894-2153

\title{
PROMENTORS PROJECT. PROMOTING MENTORS' WORK IN EDUCATION. SPRAWOZDANIE Z DZIAŁAŃ INICJUJĄCYCH PROJEKT
}

Od lutego bieżącego roku Instytut Pedagogiki Katolickiego Uniwersytetu Lubelskiej Jana Pawła II uczestniczy w międzynarodowym projekcie pt. Promoting Mentors' Work in Education, współfinansowanym w ramach programu Unii Europejskiej Erasmus+. Projekt ukierunkowany jest na poprawę jakości kształcenia nauczycieli w Izraelu poprzez zbudowanie skutecznego i trwałego system mentoringu opartego na najlepszych praktykach UE. Liderem projektu jest Talpiot Academic College of Education z Izraela, a partnerami dziewięć uczelni izraelskich kształcących nauczycieli oraz cztery europejskie ośrodki akademickie: Katolicki Uniwersytet Lubelski Jana Pawła II, University of Exeter (UK), Jyväskylä University (Finlandia) oraz University of Bucharest (Rumunia).

Realizację projektu zaplanowano na trzy lata (2020-2023). W tym czasie naukowcy z Talpiot Academic College of Education, w oparciu o wybrane koncepcje mentoringu, chcą wypracować nowy model szkolenia mentorów, który zostanie wprowadzony $\mathrm{w}$ izraelskich kolegiach akademickich kształcących nauczycieli.

W projekcie uczestniczy dwunastu pracowników Instytutu Pedagogiki KUL. Kierownikiem zespołu merytorycznego jest dr hab. prof. KUL Ewa Domagała-Zyśk. Natomiast funkcję koordynatora do spraw finansowo-administracyjnych pełni dr Urszula Czyżewska (Dział Projektów Międzynarodowych KUL). 
W spotkaniu inaugurującym projekt, które odbyło się w Talpiot College w dniach 17-21 lutego 2020, brało udział czterech pracowników KUL. Koordynator projektu, dr Ewelina Świdrak i dr Agnieszka Linca-Ćwikła uczestniczyły w warsztatach projektowych. $Z$ racji sytuacji pandemicznej kolejne spotkanie (6-8.07) odbyło się zdalnie. W jego toku zaprezentowano 5 modeli mentoringu realizowanych $\mathrm{w}$ krajach biorących udział w projekcie.

Pierwszy z nich nosi nazwę SDT-Based Mentoring. Został on oparty na teorii autodeterminacji Deciego i Ryana. Model ten kładzie nacisk na optymalny rozwój obu partnerów w ramach procesu mentoringu. Według koncepcji $S D T$, oczekiwany rozwój mentora i podopiecznego ma miejsce wówczas, gdy relacja mentorska wspiera ich naturalne psychologiczne potrzeby w zakresie rozwoju relacji, kompetencji oraz autonomii.

Drugi - tzw. mentoring odwrócony (Reverse Mentoring) - wywodzi się z koncepcji Jacka Welcha. Podstawowym założeniem tego modelu jest odwrócenie tradycyjnych ról. Mianowicie - starszy pracownik, zamiast pełnić funkcję mentora dla młodszego (nowego) pracownika, w pewnym stopniu sam powinien stać się uczniem, korzystając z jego wiedzy na temat m.in. organizacji warsztatu pracy.

Trzeci model dotyczy mentoringu grupowego (Finnish model of PeerGroup Mentoring), opartego na teorii uczenia się i rozwoju zawodowego wypracowanego $\mathrm{w}$ ramach konstruktywizmu społecznego. Model ten odzwierciedla fiński system reformy edukacji, w którym kluczową rolę odgrywa wysoki poziom autonomii nauczycieli. Dlatego mentoring grup rówieśniczych opiera się głównie na wymianie doświadczeń i wiedzy specjalistycznej, odbywającej się w trakcie cyklicznych spotkań. Powstające wówczas narracje edukacyjne stają się następnie podstawą do tworzenia tożsamości zawodowej nauczycieli.

Czwarty model mentoringu oparty na tzw. Lesson Study, jest narzędziem wspierającym współpracę nauczycieli w rozwiązywaniu kluczowych kwestii praktyki pedagogicznej oraz rozwijaniu innowacyjnej i kreatywnej pedagogiki. W praktyce Lesson Study obejmuje grupę nauczycieli (zazwyczaj trzech), którzy podejmują się wspólnego planowania lekcji i angażują się w cykl nauczania, przeglądu i weryfikacji jej przebiegu.

Piąty model, zaprezentowany przez prof. Ewę Domagałę-Zyśk, przybliżył polski system kształcenia nauczycieli, uszczegółowiony o założenia antropologiczne wypracowane $\mathrm{w}$ ramach personalizmu chrześcijańskiego, jak też o dobre praktyki realizowane $\mathrm{w}$ zakresie kształcenia nauczycieli $\mathrm{w}$ ramach KUL. Koncepcja ta została wstępnie określona jako wspólnotowy model 
mentoringu nauczycielskiego (Community Model of Teacher Mentoring CMTM).

Kolejne spotkanie projektowe, połączone $\mathrm{z}$ warsztatami umożliwiającymi praktyczne poznanie modelu mentoringu grupowego, zaplanowano w Finlandii (wrzesień 2020). 